\title{
Enzymatic Procedure for the Synthesis of 11-Deoxyprostaglandins
}

\author{
Hiroshi Suemune, ${ }^{a}$ Kouji Okano, ${ }^{a}$ Hiroyuki Akita, ${ }^{b}$ \\ and KIYOSHI SAKAI ${ }^{* a}$ \\ Faculty of Pharmaceutical Sciences, Kyushu University, ${ }^{a}$ Fukuoka 812, \\ Japan and The Institute of Physical and Chemical Research, ${ }^{b}$ \\ Wako-shi, Saitama 351-01, Japan \\ (Received September 8, 1986)
}

\begin{abstract}
This paper describes the enzymatic hydrolysis of the trans, trans(meso)-2-substituted 1,3bis(acetoxymethyl)cyclopentanes $(\mathbf{4 a}, \mathbf{b})$ to afford the monoacetates $(\mathbf{5 a}, \mathbf{b})$ in high enantiomeric excess ((-)-5a: $96 \%$ ee, $(-)-5 \mathbf{b}:>99 \%$ ee). The absolute stereochemistry of (-)-5b was unequivocally determined to be $1 R, 2 R, 3 S$ by converting it to a known compound derived from ( - )-limonen10-ol. Starting with $(-)-\mathbf{5 b}$, a new route to the key intermediate $((-)-20)$ for the synthesis of 11 deoxyprostaglandins was established.
\end{abstract}

Keywords - prostaglandin; meso compound; enzymatic hydrolysis; 11-deoxyprostaglandin; (is-1,3-bis(acetoxymethyl)cyclopentane; 1,4-addition

The ability of enzymes to discriminate between enantiotopic groups of symmetrical substrates such as meso compounds is highly attractive for the synthesis of natural products. The hydrolytic enzymes have been widely investigated because many of them are capable of transforming meso-diesters into chiral monoesters. One of the synthetically useful hydrolytic enzymes is pig liver esterase (PLE). Hydrolysis of meso compounds such as monocyclic (three-, four-, and six-membered) ring derivatives with cis-1,2-dimethyl esters by commercially available PLE proceeds with high enantioselectivity. ${ }^{1)}$ However, cis-1,2- and cis-1,3bis(methoxycarbonyl)cyclopentanes are hydrolyzed to the corresponding half esters with only $17^{1 a)}$ and $34 \%$ ee, ${ }^{2)}$ respectively. According to Laumen and Schneider, ${ }^{1 c)}$ and Jones et al., ${ }^{3)}$ enzymatic hydrolysis of cis-1,2-bis(acetoxymethyl)cyclopentane ${ }^{4)}$ with PLE or pig pancreatic lipase (PPL) affords the corresponding hydroxy ester in good yield and with fairly good optical purity $(88-89 \%$ ee). This result is in marked contrast to-that of the hydrolysis of the dimethyl esters.

We now report that the enzymatic hydrolysis of the trans, trans(meso)-2-substituted 1,3bis(acetoxymethyl)cyclopentanes proceeds in a highly enantioselective manner to afford the chiral monoacetates, which provide the new route to the synthesis of a key intermediate ${ }^{5)}$ for 11-deoxyprostaglandins (PGs).

The trans, trans(meso)-2-substituted 1,3-bis(acetoxymethyl)cyclopentanes used as substrates were synthesized from 1,3-bis(methoxycarbonyl)-1-cyclopentene (1) ${ }^{6}$ as follows. The 1,4-addition of 1 with $\mathrm{BuCuBF}_{3}$, prepared from $\mathrm{BuLi}, \mathrm{CuI}$, and $\mathrm{BF}_{3}$ etherate, afforded a mixture of the trans, trans(meso) compound (2a) and the cis, trans compound (3a) in $70 \%$ yield in the ratio of 2 (2a) to 1 (3a), and these products could be separated by flash chromatography. In the proton nuclear magnetic resonance $\left({ }^{1} \mathrm{H}-\mathrm{NMR}\right)$ spectrum of the less polar fraction (2a), the signals of the $\mathrm{C}_{1}-\mathrm{H}$ and $\mathrm{C}_{3}-\mathrm{H}$ protons were observed as a broad singlet $\left(W_{1 / 2}=14 \mathrm{~Hz}\right)$ at $\delta 2.47$, and two methyl signals due to $\mathrm{C}_{1}$ - and $\mathrm{C}_{3}-\mathrm{COOCH}_{3}$ appeared as a singlet peak at $\delta 3.67$, whereas those of the more polar fraction (3a) were observed as separate 


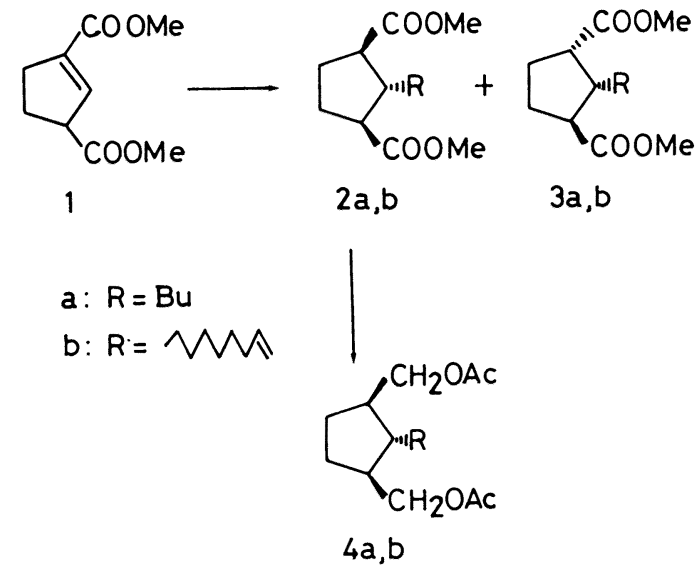

Chart 1

TABLE I. Enzymatic Hydrolysis of $\mathbf{4 a}, \mathbf{b}$

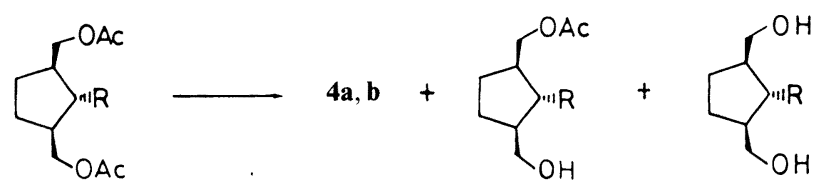

4a, b $\quad 5 a, b \quad 6 a, b$

\begin{tabular}{|c|c|c|c|c|c|c|c|c|}
\hline \multirow{2}{*}{ Run } & \multirow{2}{*}{ Compd. ${ }^{a)}$} & \multirow{2}{*}{$\begin{array}{c}\text { Enzyme } \\
(\mathrm{mg})\end{array}$} & \multicolumn{3}{|c|}{ Chem. yield $(\%)$} & \multirow{2}{*}{$\begin{array}{l}\text { Reaction } \\
\text { time }(\mathrm{h})\end{array}$} & \multicolumn{2}{|c|}{5} \\
\hline & & & 4 & 5 & 6 & & $\% \mathrm{ee}^{b)}$ & {$[\alpha]_{\mathrm{D}}^{20}\left(\mathrm{CDCl}_{3}\right)$} \\
\hline \multirow[t]{2}{*}{1} & $\mathbf{4 a}$ & PPL (26) & 46 & 41 & 5 & 14 & 66 & $-1.39^{\circ}$ \\
\hline & $4 b$ & PPL (12) & 39 & 44 & 4 & 20 & 63 & -2.13 \\
\hline \multirow[t]{2}{*}{2} & $4 \mathbf{a}$ & PLE (3.1) & 68 & 4 & 16 & 1.5 & 23 & +0.52 \\
\hline & $4 b$ & PLE (1.5) & 85 & 3 & 1 & 2.0 & 59 & $+2.10^{\circ}$ \\
\hline \multirow[t]{2}{*}{3} & $4 a$ & RDL (14) & 34 & 62 & 0 & 20 & 96 & $-2.31^{\circ}$ \\
\hline & $4 b$ & RDL (6.2) & 18 & 69 & 5 & 68 & $>99$ & -3.68 \\
\hline \multirow[t]{2}{*}{4} & $4 \mathbf{a}$ & -c) & & & & & & \\
\hline & $4 b$ & CCL (24.8) & 65 & 14 & 1 & 48 & 21 & +1.20 \\
\hline
\end{tabular}

a) Scale of hydrolysis, $\mathbf{a}=350, \mathbf{b}=200 \mathrm{mg}$. b) Optical purities were determined by examination of the $400 \mathrm{MHz}{ }^{1} \mathrm{H}-\mathrm{NMR}$ spectra after conversion of the products to the esters of $(+)-\alpha$-methoxy- $\alpha$-trifluoromethylphenylacetic acid (MTPA). ${ }^{8)} c$ ) Not tested.

peaks (see Experimental). These data suggest that compound 2a is a meso form. By assuming approach of the reagent from the less-hindered side of the sterically hindered double bond, the structure of $\mathbf{2 \mathbf { a } ^ { 7 }}$ and 3a were determined to be 1,2-trans-2,3-trans(meso) and 1,2-cis-2,3-trans, respectively. In a similar manner, $\mathbf{2 b}$ and $\mathbf{3 b}$ were synthesized from $\mathbf{1}$ and the cuprate reagent, prepared from 8-bromo-1-octene via 8-lithio-1-octene. Reduction of 2 with $\mathrm{LiAlH}_{4}$ followed by treatment with $\mathrm{Ac}_{2} \mathrm{O} / \mathrm{Py}$ afforded the trans, trans(meso)-2-substituted 1,3-bis(acetoxymethyl)cyclopentanes (4).

Enzymatic hydrolyses of 4 were performed in $0.1 \mathrm{M}$ phosphate buffer solution ( $\mathrm{pH} 7)$ at $30{ }^{\circ} \mathrm{C}$ (Table I). Among the four tested enzymes, PLE, PPL, Rhizopus delemar lipase (RDL), and Candida cylindracea lipase (CCL), RDL afforded the (-)-monoacetate (5) in fairly good yield and with high enantiomeric excess $((-)-5 \mathbf{a}: 96 \%$ ee, $(-)-5 \mathbf{b}:>99 \%$ ee). It is noteworthy 
that the hydrolysis of $\mathbf{4 b}$ with CCL (or PLE) afforded the (+)-monoacetate $(\mathbf{5 b})$, whereas PPL (or RDL) gave the $(-)$-monoacetate $(\mathbf{5 b})$, although the absolute values of specific rotation are not always identical (see Table I).

The absolute stereochemistry of the hydrolyzed product $((-)-5 \mathbf{b})$ was unambiguously determined by converting it to a known compound (12 $)^{9)}$ derived from (-)-limonen-10-ol, via the removal of the unnecessary hydroxymethyl function. Upon catalytic hydrogenation with $\mathrm{H}_{2} / \mathrm{Pt}$ in EtOH and subsequent Swern oxidation ( $(\mathrm{COCl})_{2} /$ dimethyl sulfoxide (DMSO)) in the presence of triethylamine, (-)-5b afforded the aldehyde $(\mathbf{8})$ in $86 \%$ yield. The aldehyde function in $\mathbf{8}$ was smoothly removed by heating in benzonitrile in the presence of Wilkinson complex, and the acetoxy function was reductively transformed into the corresponding<smiles>CC(=O)OCC1CCCC1CO</smiles>

$(-)-5 b$

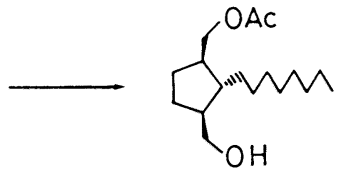

7

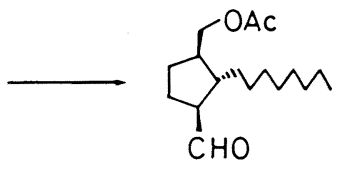

8

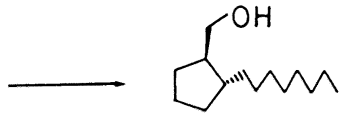

9

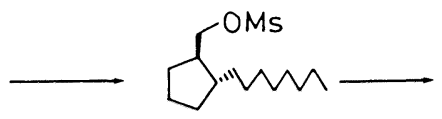

10

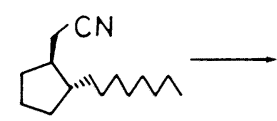

11

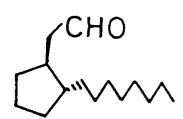

$(-)-12$ $(-)$-limonen-10-ol

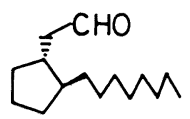

(t) -12

Chart 2

alcohol by treatment with $\mathrm{LiAlH}_{4}$. Mesylation of the alcohol (9) with methanesulfonyl chloride/Py followed by substitution with $\mathrm{NaCN} / \mathrm{DMSO}$ afforded the nitrile (11) in $78 \%$ yield from 9. By reduction with diisobutylaluminum hydride (DIBAL-H) and subsequent hydrolysis with $10 \% \mathrm{H}_{2} \mathrm{SO}_{4}, 11$ was converted into the aldehyde ((-)-12). The aldehyde (-)-12 was identical with the standard sample $(+)-12^{9)}$ in terms of the ${ }^{1} \mathrm{H}-\mathrm{NMR}$ spectrum, the infrared (IR) spectrum and thin-layer chromatographic (TLC) behavior, except for the sign of specific rotation. Thus, the absolute stereochemistry of (-)-5b was unequivocally determined to be $1 R, 2 R, 3 S$.

In the synthesis of 11-deoxy PGs, the absolute stereochemistry of (-)-5b suggests that the $\mathrm{C}_{1}-\mathrm{CH}_{2} \mathrm{OCOCH}_{3}$ group in (-)-5b should be converted to the ketone in the fivemembered ring. Conversion of $(-)-5 \mathbf{b}$ to the intermediate $((-)-20)$ for 11-deoxy PGs proceeded smoothly with retention of the stereochemistry at $C_{2}$ and $C_{3}$ in (-)-5b. The alcohol function in (-)-5b was first protected with 2-methoxyethoxymethyl chloride (MEM chloride) $/ N, N$-diisopropylethylamine to afford the MEM ether (13), and the acetoxy function was converted to the corresponding alcohol with $\mathrm{LiAlH}_{4}$. In order to facilitate the elimination of the alcohol to form the double bond, the alcohol (14) was subjected to mesylation with methanesulfonyl chloride/ $\mathrm{Et}_{3} \mathrm{~N}$ and subsequent substitution with $\mathrm{NaI}$ in hexamethylphosphoramide (HMPA). Dehydroiodination of the iodide (16) with tert-BuOK in DMSO at room temperature afforded the diene (17) in $68 \%$ yield from (-)-5b. Concurrent cleavage of the two double bonds in 17 with ozone in $\mathrm{CH}_{2} \mathrm{Cl}_{2}$, followed by treatment with $\mathrm{Zn} / \mathrm{AcOH}$, gave the keto-aldehyde (18) in $76 \%$ yield. By Jones oxidation of the aldehyde function to the corresponding acid, followed by treatment with $\mathrm{CH}_{2} \mathrm{~N}_{2}$, 18 was converted to 


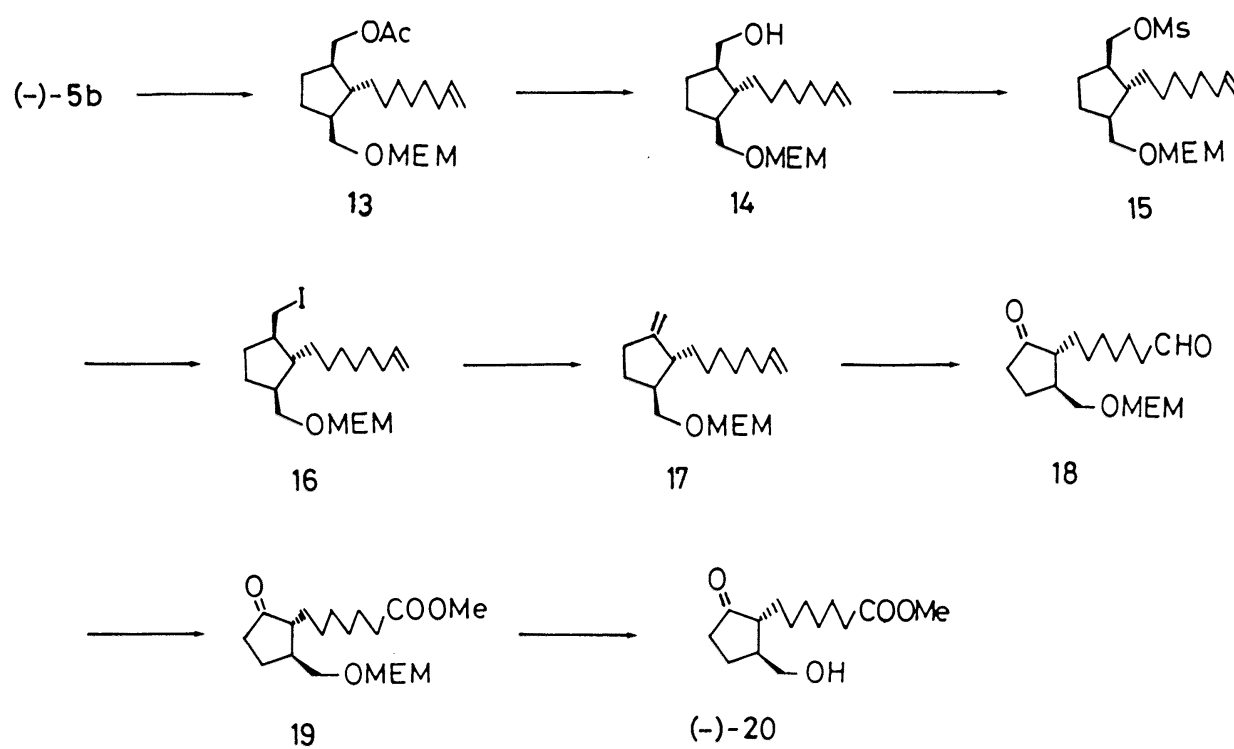

Chart 3

the ester (19), and the MEM function was removed by treatment with $\mathrm{TiCl}_{4}$ to afford the intermediate $((-)-20),{ }^{10)}$ whose ${ }^{1} \mathrm{H}$-NMR spectrum and IR spectrum were identical with those of a standard sample. ${ }^{11)}$

Thus, this synthetic method using enzymatic hydrolysis of meso compounds seems to be useful for the synthesis of the optically active target (-)-20.

\section{Experimental}

IR spectra were measured with a JASCO A-202 spectrometer. ${ }^{1} \mathrm{H}-\mathrm{NMR}$ spectra were measured on a JEOL-PS100 spectrometer. Mass spectra (MS) were taken on a JEOL JMS-D 300 spectrometer. Optical rotations were measured on a JASCO DIP-4 polarimeter. For column chromatography and flash chromatography, silica gel 70 230 mesh (Merck, Kieselgel 60) and 230 - 400 mesh (Nakarai Chemicals, Silica gel 60) were used, respectively. TLC was performed on Silica gel $60 \mathrm{~F}_{254}$ plates (Merck). For enzymatic hydrolysis, PLE (Sigma, type I), PPL (Sigma, type II (pfs)), CCL (Sigma, type VII (pfs)) and RDL (Seikagaku Kogyo, fine grade) were used. All organic solvent extracts were washed with satd. brine and dried over anhydrous sodium sulfate.

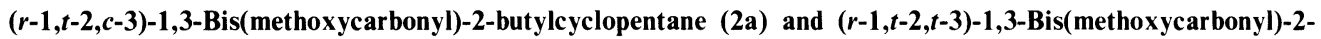
butylcyclopentane (3a) - $\mathrm{BuLi}(1.5 \mathrm{M}$ in hexane, $10.9 \mathrm{ml})$ solution was added dropwise with stirring to a suspension of $\mathrm{CuI}(3.11 \mathrm{~g})$ in ether $(30 \mathrm{ml})$ at $-40^{\circ} \mathrm{C}$ under an $\mathrm{Ar}$ atmosphere. After $0.5 \mathrm{~h}, \mathrm{BF}_{3}$ etherate $(2.12 \mathrm{ml})$ was added dropwise at $-78^{\circ} \mathrm{C}$. The mixture was stirred for $0.5 \mathrm{~h}$, the diester $(1,1.003 \mathrm{~g})$ in ether $(3 \mathrm{ml})$ was added dropwise, and the whole was stirred for $1 \mathrm{~h}$ at $-78^{\circ} \mathrm{C}$, then for $1 \mathrm{~h}$ at $-10^{\circ} \mathrm{C}$. The reaction mixture was diluted with satd. $\mathrm{NH}_{4} \mathrm{Cl}$, and extracted with ether. The ether extract was washed and dried. The solvent was removed in vacuo to afford an oily residue, which was roughly chromatographed on silica gel $(10 \mathrm{~g})$. The fraction eluted with $10 \% \mathrm{AcOEt}$ in hexane $(\mathrm{v} / \mathrm{v})$ afforded a mixture of $\mathbf{2 a}$ and $\mathbf{3 a}(1.10 \mathrm{~g})$, which was subjected to flash chromatography using $2 \%$ AcOEt in hexane $(\mathrm{v} / \mathrm{v}) .2 \mathrm{a}(702 \mathrm{mg}, 53 \%)$ and $\mathbf{3 a}(344 \mathrm{mg}, 26 \%)$ were obtained from the less polar fraction and the more polar fraction, respectively. 2a: IR (neat): 1735, 1430, $1155 \mathrm{~cm}^{-1} .{ }^{1} \mathrm{H}-\mathrm{NMR}\left(\mathrm{CDCl}_{3}\right) \delta: 0.87\left(3 \mathrm{H}, \mathrm{t}, J=6 \mathrm{~Hz}, \mathrm{CH}_{3}\right), 2.47(2 \mathrm{H}, \mathrm{br} \mathrm{s}$, $\mathrm{CHCO} \times 2), 3.67\left(6 \mathrm{H}, \mathrm{s}, \mathrm{COOCH}_{3} \times 2\right)$. MS $m / z: 242\left(\mathrm{M}^{+}\right), 211,102.3 \mathrm{a}: \mathrm{IR}$ (neat): $1735,1435,1160 \mathrm{~cm}^{-1} .{ }^{1} \mathrm{H}-\mathrm{NMR}$ $\left(\mathrm{CDCl}_{3}\right) \delta: 0.86\left(3 \mathrm{H}, \mathrm{t}, J=6 \mathrm{~Hz}, \mathrm{CH}_{3}\right), 2.71\left(1 \mathrm{H}, \mathrm{m}, \mathrm{C}_{3}-\mathrm{H}\right),{ }^{12)} 3.00\left(1 \mathrm{H}, \mathrm{m}, \mathrm{C}_{1}-\mathrm{H}\right), 3.64\left(3 \mathrm{H}, \mathrm{s}, \mathrm{COOCH}_{3}\right), 3.67(3 \mathrm{H}, \mathrm{s}$, $\left.\mathrm{COOCH}_{3}\right)$. MS $m / z: 242\left(\mathrm{M}^{+}\right), 210,182$.

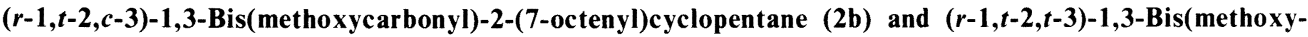
carbonyl)-2-(7-octenyl)cyclopentane (3b) -8 -Bromo-1-octene $(5.00 \mathrm{~g})$ in ether $(20 \mathrm{ml})$ was added dropwise with stirring to a suspension of lithium (high sodium, $25 \%(\mathrm{w} / \mathrm{w})$ dispersion in mineral oil, $2.45 \mathrm{~g}$ ) in ether $(50 \mathrm{ml})$ in the presence of 1,2-dibromoethane $(0.2 \mathrm{ml})$ at $-40^{\circ} \mathrm{C}$ under an $\mathrm{Ar}$ atmosphere. The resulting 8-lithio-1-octene solution was added dropwise to a stirred solution of $\mathrm{CuI}(4.29 \mathrm{~g})$ in ether $(50 \mathrm{ml})$ at $-40{ }^{\circ} \mathrm{C}$. After $0.5 \mathrm{~h}, \mathrm{BF}_{3}$ etherate $(2.93 \mathrm{ml})$ was added dropwise at $-78^{\circ} \mathrm{C}$, and the mixture was stirred for $0.5 \mathrm{~h}$, then the diester $(\mathbf{1}, 1.381 \mathrm{~g})$ in ether $(5 \mathrm{ml})$ was 
added dropwise. Stirring was continued for $3 \mathrm{~h}$ at $-78^{\circ} \mathrm{C}$, and for $1 \mathrm{~h}$ at $0 \circ \mathrm{C}$, and work-up similar to that described for the synthesis of $\mathbf{2 a}$ and $3 \mathbf{a}$ afforded $\mathbf{2 b}(1.40 \mathrm{~g}, 63 \%)$ and $\mathbf{3 b}(515 \mathrm{mg}, 23 \%)$ as colorless oils. $2 \mathbf{b}$ : IR (neat): 1740 , $1640,910 \mathrm{~cm}^{-1} .{ }^{1} \mathrm{H}-\mathrm{NMR}\left(\mathrm{CDCl}_{3}\right) \delta: 2.46(2 \mathrm{H}, \mathrm{brs}, \mathrm{CHCO} \times 2), 3.67\left(6 \mathrm{H}, \mathrm{s}, \mathrm{COOCH}_{3} \times 2\right), 4.84-5.15(2 \mathrm{H}, \mathrm{m}$, $\left.=\mathrm{CH}_{2}\right), 5.80(1 \mathrm{H}, \mathrm{m}, \mathrm{CH}=)$. MS $m / z: 297\left(\mathrm{M}^{+}+1\right), 296\left(\mathrm{M}^{+}\right), 265,232.3 \mathrm{~b}:$ IR (neat): $1735,1640,910 \mathrm{~cm}^{-1} .{ }^{1} \mathrm{H}^{-}$ $\operatorname{NMR}\left(\mathrm{CDCl}_{3}\right) \delta: 2.70\left(1 \mathrm{H}, \mathrm{m}, \mathrm{C}_{3}-\mathrm{H}\right),{ }^{12)} 3.02\left(1 \mathrm{H}, \mathrm{m}, \mathrm{C}_{1}-\mathrm{H}\right), 3.64\left(3 \mathrm{H}, \mathrm{s}, \mathrm{COOCH}_{3}\right), 3.66\left(3 \mathrm{H}, \mathrm{s}, \mathrm{COOCH}_{3}\right), 4.82-$ $5.10\left(2 \mathrm{H}, \mathrm{m},=\mathrm{CH}_{2}\right), 5.80(1 \mathrm{H}, \mathrm{m}, \mathrm{CH}=)$. MS $m / z: 297\left(\mathrm{M}^{+}+1\right), 296\left(\mathrm{M}^{+}\right), 264,232$.

$(r-1, t-2, c-3)-1,3-B i s($ acetoxymethyl)-2-butylcyclopentane (4a) and $(r-1, t-2, c-3)-1,3-B i s($ acetoxymethyl)-2-(7octenyl)cyclopentane (4b) - The diester $2 \mathbf{a}(484 \mathrm{mg})$ in ether $(5 \mathrm{ml})$ was added dropwise with stirring to a suspension of $\mathrm{LiAlH}_{4}(114 \mathrm{mg})$ in ether $(5 \mathrm{ml})$ at $0 \mathrm{C}$. After $2 \mathrm{~h}$, the reaction mixture was subjected to usual work-up to afford the crude diol $(310 \mathrm{mg})$, which was acetylated in a usual manner. The crude diacetate $(450 \mathrm{mg})$ was purified by column chromatography on silica gel $(10 \mathrm{~g})$, and the fraction eluted with $20 \%$ AcOEt in hexane $(\mathrm{v} / \mathrm{v})$ afforded $4 \mathbf{a}(352 \mathrm{mg}$, $92 \%$ ) as a colorless oil. Similarly, $\mathbf{4 b}$ was obtained in $94 \%$ yield from $\mathbf{2 b}$. $4 \mathbf{a}$ : IR (neat): $1740,1240,1030 \mathrm{~cm}^{-1} .{ }^{1} \mathrm{H}_{-}$ $\operatorname{NMR}\left(\mathrm{CDCl}_{3}\right) \delta: 0.89(3 \mathrm{H}, \mathrm{t}, J=6 \mathrm{~Hz}), 2.06\left(6 \mathrm{H}, \mathrm{s}, \mathrm{COCH}_{3} \times 2\right) . \mathrm{MS} m / z: 270\left(\mathrm{M}^{+}\right), 223,211.4 \mathrm{~b}:$ IR (neat): 1735 , $1635,1230 \mathrm{~cm}^{-1} .{ }^{1} \mathrm{H}-\mathrm{NMR}\left(\mathrm{CDCl}_{3}\right) \delta: 2.05\left(6 \mathrm{H}, \mathrm{s}, \mathrm{COCH}_{3} \times 2\right), 4.82-5.12\left(2 \mathrm{H}, \mathrm{m},=\mathrm{CH}_{2}\right), 5.78(1 \mathrm{H}, \mathrm{m}, \mathrm{CH}=)$. MS $m / z: 325\left(\mathrm{M}^{+}+1\right), 264,222$.

General Method for the Enzymatic Hydrolysis. A Typical Example: Hydrolysis of $4 \mathrm{~b}$ to $(1 R, 2 R, 3 S)$-1Acetoxymethyl-2-(7-octenyl)-3-hydroxymethylcyclopentane (5b) with $\mathbf{R D L}$-Compound $\mathbf{4 b}$ (200 $\mathrm{mg}$ ) in acetone $(' \mathrm{ml})$ and RDL $(6.2 \mathrm{mg})$ were successively added with stirring to $0.1 \mathrm{M}$ phosphate buffer $(10 \mathrm{ml}, \mathrm{pH} 7)$. The whole was stirred at $30 \mathrm{C}$, and hydrolysis was terminated by extracting the mixture with AcOEt when a spot of the diol (6b) appeared on TLC. The AcOEt extract was washed and dried, then concentrated in vacuo to leave an oily residue, which was purified by column chromatography on silica gel $(6 \mathrm{~g})$. The fraction eluted with $3 \%$ AcOEt in hexane $(\mathrm{v} / \mathrm{v})$ afforded $(-)-5 \mathbf{b}(120 \mathrm{mg}, 69 \%)$ as a colorless oil. $[\alpha]_{\mathrm{D}}^{20}-3.68^{\circ}\left(c=2.18, \mathrm{CHCl}_{3}\right)$. IR (neat): 3400, 1735, 1635, $1240 \mathrm{~cm}^{-1} .{ }^{1} \mathrm{H}-\mathrm{NMR}\left(\mathrm{CDCl}_{3}\right) \delta: 2.06\left(3 \mathrm{H}, \mathrm{s}, \mathrm{COCH}_{3}\right), 3.42\left(1 \mathrm{H}, \mathrm{dd}, J=11,7 \mathrm{~Hz}, \mathrm{CH}_{\mathrm{A}} \mathrm{H}_{\mathrm{B}} \mathrm{OH}\right), 3.82(1 \mathrm{H}, \mathrm{dd}, J=11$, $\left.5 \mathrm{~Hz}, \mathrm{CH}_{\mathrm{A}} \mathrm{H}_{\mathrm{B}}-\mathrm{OH}\right), 3.88\left(1 \mathrm{H}, \mathrm{dd}, J=10.5,6.5 \mathrm{~Hz}, \mathrm{CH}_{\mathrm{A}} \mathrm{H}_{\mathrm{B}}-\mathrm{OAc}\right), 4.04\left(1 \mathrm{H}, \mathrm{dd}, J=10.5,5.5 \mathrm{~Hz}, \mathrm{CH}_{\mathrm{A}} \mathrm{H}_{\mathrm{B}}-\mathrm{OAc}\right)$. MS $m / z: 283\left(\mathrm{M}^{+}+1\right), 252,234$. Anal. Calcd for $\mathrm{C}_{17} \mathrm{H}_{30} \mathrm{O}_{3}: \mathrm{C}, 72.30 ; \mathrm{H}, 10.71$. Found: C, 72.43; H, 10.77.

$(1 R, 2 R, 3 S)$-1-Acetoxymethyl-3-hydroxymethyl-2-octylcyclopentane (7)-A solution of (-)-5b (638 mg) in EtOH $(50 \mathrm{ml})$ was hydrogenated in the presence of $\mathrm{PtO}_{2}(100 \mathrm{mg})$ under an $\mathrm{H}_{2}$ atmosphere for $5 \mathrm{~h}$. The catalyst was filtered off, and the filtrate was concentrated in vacuo to afford an oily residue, which was purified by column chromatography on silica gel $(13 \mathrm{~g})$. The fraction eluted with $3 \%$ AcOEt in hexane (v/v) afforded $7(613 \mathrm{mg}, 95 \%)$ as a colorless oil. $[\alpha]_{\mathrm{D}}^{17}-2.73\left(c=1.21, \mathrm{CHCl}_{3}\right)$. IR (neat): $3400,1735,1235 \mathrm{~cm}^{-1} \cdot{ }^{1} \mathrm{H}-\mathrm{NMR}\left(\mathrm{CDCl}_{3}\right) \delta: 0.87(3 \mathrm{H}, \mathrm{t}, J=$ $\left.6 \mathrm{~Hz}, \mathrm{CH}_{3}\right), 2.05\left(3 \mathrm{H}, \mathrm{s}, \mathrm{COCH}_{3}\right), 3.28-3.72\left(2 \mathrm{H}, \mathrm{m}, \mathrm{CH}_{2} \mathrm{OH}\right), 3.76-4.24\left(2 \mathrm{H}, \mathrm{m}, \mathrm{CH}_{2} \mathrm{OAc}\right) . \mathrm{MS} m / z: 285$ $\left(\mathrm{M}^{+}+1\right), 254,241$.

$(\mathbf{R}, 2 S, 3 S)$-1-Acetoxymethyl-3-formyl-2-octylcyclopentane (8)-DMSO $(375 \mathrm{mg})$ in $\mathrm{CH}_{2} \mathrm{Cl}_{2}(1 \mathrm{ml})$ was added to a stirred solution of $(\mathrm{COCl})_{2}(305 \mathrm{mg})$ in $\mathrm{CH}_{2} \mathrm{Cl}_{2}(3 \mathrm{ml})$ at $-60^{\circ} \mathrm{C}$ under an Ar atmosphere. After $5 \mathrm{~min}, 7(620 \mathrm{mg})$ in $\mathrm{CH}_{2} \mathrm{Cl}_{2}(2 \mathrm{ml})$ was added, and the whole was stirred for $15 \mathrm{~min}$, then triethylamine $(1.11 \mathrm{~g})$ in $\mathrm{CH}_{2} \mathrm{Cl}_{2}(5 \mathrm{ml})$ was added at $-60 \mathrm{C}$. After $20 \mathrm{~min}$, the reaction mixture was warmed to room temperature, diluted with brine $(20 \mathrm{ml})$, and then extracted with AcOEt. The AcOEt extract was successively washed with $3 \%$ aq. $\mathrm{HCl}, 5 \%$ aq. $\mathrm{NaHCO}_{3}$, and brine, then dried. Removal of the solvent in vacuo gave an oily residue, which was purified by column chromatography on silica gel $(15 \mathrm{~g})$. The fraction eluted with $2 \%$ AcOEt in hexane $(\mathrm{v} / \mathrm{v})$ afforded $\mathbf{8}(559 \mathrm{mg}, 91 \%)$ as a colorless oil. $[\alpha]_{\mathrm{D}}^{17}-19.6^{\circ}\left(c=1.04, \mathrm{CHCl}_{3}\right)$. IR (neat): $2700,1735,1720,1235 \mathrm{~cm}^{-1} .{ }^{1} \mathrm{H}-\mathrm{NMR}\left(\mathrm{CDCl}_{3}\right) \delta: 2.06(3 \mathrm{H}$, $\left.\mathrm{s}, \mathrm{COCH}_{3}\right), 2.48(1 \mathrm{H}, \mathrm{m}, \mathrm{CH}-\mathrm{CHO}), 9.61(1 \mathrm{H}, \mathrm{d}, J=2 \mathrm{~Hz}, \mathrm{CHO}) . \mathrm{MS} m / z: 281\left(\mathrm{M}^{+}-1\right), 253,237,210$.

$(1 R, 2 R)$-1-Hydroxymethyl-2-octylcyclopentane (9)_-A mixture of $8(577 \mathrm{mg})$ and Wilkinson complex (2.08 g) in benzonitrile $(25 \mathrm{ml})$ was heated with stirring for $5 \mathrm{~h}$ at $160^{\circ} \mathrm{C}$. The solvent was removed in vacuo, and EtOH $(20 \mathrm{ml})$ was added to yield a precipitate, which was filtered off. The filtrate was concentrated in vacuo to afford an oily residue which was roughly chromatographed on silica gel $(20 \mathrm{~g})$. The fraction eluted with $20 \%$ AcOEt in hexane $(\mathrm{v} / \mathrm{v})$ afforded the monoacetate contaminated with triphenylphosphine. The crude acetate $(250 \mathrm{mg})$ in ther $(5 \mathrm{ml})$ was added dropwise with stirring to a suspension of $\mathrm{LiAlH}_{4}(56 \mathrm{mg})$ in ether $(5 \mathrm{ml})$ at room temperature, and the whole was stirred for $1 \mathrm{~h}$. The usual work-up afforded a crude oil $(183 \mathrm{mg})$, which was purified by column chromatography on silica gel $(20 \mathrm{~g})$. The fraction eluted with $10 \%$ AcOEt in hexane $(\mathrm{v} / \mathrm{v})$ afforded $9(185 \mathrm{mg})$ as a colorless oil. $[\alpha]_{546}^{17}$ $-55.7^{\circ} .\left(c=1.12, \mathrm{CHCl}_{3}\right)$. IR (neat): $3310,1020 \mathrm{~cm}^{-1} .{ }^{1} \mathrm{H}-\mathrm{NMR}\left(\mathrm{CDCl}_{3}\right) \delta: 0.88\left(3 \mathrm{H}, \mathrm{t}, \mathrm{J}=6 \mathrm{~Hz}, \mathrm{CH}_{3}\right), 3.30-3.76$ $\left(2 \mathrm{H}, \mathrm{m}, \mathrm{CH}_{2} \mathrm{OH}\right)$. MS $m / z: 211\left(\mathrm{M}^{+}-1\right), 194,179$.

$(1 R, 2 R)$-1-Mesyloxymethyl-2-octylcyclopentane (10)_-Methanesulfonyl chloride $(142 \mathrm{mg})$ in benzene $(2 \mathrm{ml})$ was added dropwise to a stirred solution of $9(175 \mathrm{mg})$ in benzene $(5 \mathrm{ml})$ in the presence of $\mathrm{Et}_{3} \mathrm{~N}(167 \mathrm{mg})$ at room temperature. After $2 \mathrm{~h}$, the reaction mixture was diluted with $5 \%$ aq. $\mathrm{HCl}(10 \mathrm{ml})$, and extracted with AcOEt. The AcOEt extract was successively washed with $5 \%$ aq. $\mathrm{NaHCO}_{3}, 5 \%$ aq. $\mathrm{HCl}$, and brine, then dried. Removal of the solvent in vacuo afforded an oily residue, which was subjected to column chromatography on silica gel (10 g). The fraction eluted with $10 \%$ AcOEt in hexane $(\mathrm{v} / \mathrm{v})$ afforded $10(207 \mathrm{mg}, 87 \%)$ as a colorless oil. $[\alpha]_{\mathrm{D}}^{22}-39.1^{\circ}(c=1.03$, $\left.\mathrm{CHCl}_{3}\right)$. IR (neat): $1355,1170,945 \mathrm{~cm}^{-1} \cdot{ }^{1} \mathrm{H}-\mathrm{NMR}\left(\mathrm{CDCl}_{3}\right) \delta: 0.88\left(3 \mathrm{H}, \mathrm{t}, J=6 \mathrm{~Hz}, \mathrm{CH}_{3}\right), 3.00\left(3 \mathrm{H}, \mathrm{s}, \mathrm{SO}_{2} \mathrm{CH}_{3}\right)$, $3.93-4.32\left(2 \mathrm{H}, \mathrm{m}, \mathrm{CH}_{2} \mathrm{O}\right)$.

$(1 R, 2 R)$-1-Cyanomethyl-2-octylcyclopentane (11) - A mixture of $10(83 \mathrm{mg})$ and $\mathrm{NaCN}(20 \mathrm{mg})$ in DMSO $(5 \mathrm{ml})$ 
was heated with stirring at $100 \mathrm{C}$. After $4 \mathrm{~h}$, the reaction mixture was diluted with $\mathrm{H}_{2} \mathrm{O}(10 \mathrm{ml})$, and extracted with AcOEt. The AcOEt extract was washed, and dried. The solvent was removed in vacuo to afford an oily residue, which was purified by column chromatography on silica gel $(3 \mathrm{~g})$. The fraction eluted with $5 \%$ AcOEt in hexane $(\mathrm{v} / \mathrm{v})$ gave $11(57 \mathrm{mg})$ as a colorless oil. $[\alpha]_{\mathrm{D}}^{25}-62.7^{\circ}\left(c=0.81, \mathrm{CHCl}_{3}\right)$. IR (neat): $2240,1460 \mathrm{~cm}^{-1}$. ${ }^{1} \mathrm{H}-\mathrm{NMR}$ $\left(\mathrm{CDCl}_{3}\right) \delta: 0.88\left(3 \mathrm{H}, \mathrm{t}, J=6 \mathrm{~Hz}, \mathrm{CH}_{3}\right), 2.10-2.64\left(2 \mathrm{H}, \mathrm{m}, \mathrm{CH}_{2} \mathrm{CN}\right) . \mathrm{MS} m / z: 220\left(\mathrm{M}^{+}-1\right), 206,192$.

$(1 R, 2 R)$-1-Formylmethyl-2-octylcyclopentane (12)_DIBAL-H (tetrahydrofuran solution) $(0.4 \mathrm{ml})$ was added dropwise to a stirred solution of $11(45 \mathrm{mg})$ in hexane $(5 \mathrm{ml})$ at $-70 \mathrm{C}$. The whole was stirred for $0.5 \mathrm{~h}$ at $-60 \mathrm{C}$, and for $5 \mathrm{~h}$ at $0 \mathrm{C}$, then diluted with $10 \% \mathrm{H}_{2} \mathrm{SO}_{4}(10 \mathrm{ml})$, and extracted with AcOEt. The AcOEt extract was washed, and dried, then concentrated in vacuo to leave an oily residue, which was subjected to column chromatography on silica gel $(3 \mathrm{~g})$. The fraction eluted with $10 \%$ ether in hexane $(\mathrm{v} / \mathrm{v})$ afforded $(-)-12(19 \mathrm{mg})$ as a colorless oil. $[x]_{\mathrm{D}}^{20}-47.6$ $\left(c=0.84, \mathrm{CHCl}_{3}\right)($ the reported value: +43.6$) \cdot{ }^{8)} \mathrm{IR}$ (neat): $2710,1730,1030 \mathrm{~cm}^{-1} .{ }^{1} \mathrm{H}-\mathrm{NMR}\left(\mathrm{CDCl}_{3}\right) \delta: 0.88(3 \mathrm{H}, \mathrm{t}$, $\left.J=6 \mathrm{~Hz}, \mathrm{CH}_{3}\right), 2.25\left(1 \mathrm{H}, \mathrm{ddd}, J=16,8,2.5 \mathrm{~Hz}, \mathrm{CH}_{\mathrm{A}} \mathrm{H}_{\mathrm{B}}-\mathrm{CHO}\right), 2.59\left(1 \mathrm{H}\right.$, ddd, $\left.J=16,6.5,2.5 \mathrm{~Hz}, \mathrm{CH}_{\mathrm{A}} \mathrm{H}_{\mathrm{B}}-\mathrm{CHO}\right)$, $9.77(1 \mathrm{H}, \mathrm{t}, J=2.5 \mathrm{~Hz}, \mathrm{CHO})$. MS $m / z: 225\left(\mathrm{M}^{+}+1\right), 224\left(\mathrm{M}^{+}\right), 206,193$. Anal. Calcd for $\mathrm{C}_{15} \mathrm{H}_{28} \mathrm{O}: \mathrm{C}, 80.29 ; \mathrm{H}$, 12.58. Found: $\mathrm{C}, 80.10 ; \mathrm{H}, 12.71$.

$(1 R, 2 R, 3 S)$-1-Acetoxymethyl-3-(2-methoxyethoxymethoxymethyl)-2-(7-octenyl)cyclopentane (13) — MEM chloride $(618 \mathrm{mg})$ in $\mathrm{CH}_{2} \mathrm{Cl}_{2}(3 \mathrm{ml})$ was added dropwise to a stirred solution of $(-)-\mathbf{5 b}(350 \mathrm{mg})$ in the presence of $N, N$-diisopropylethylamine $(650 \mathrm{mg})$. After $3 \mathrm{~h}$, the reaction mixture was diluted with brine $(15 \mathrm{ml})$, and extracted with AcOEt. The AcOEt extract was washed, and dried, then removal of the solvent in vacuo afforded an oily residue, which was chromatographed on silica gel $(30 \mathrm{~g})$. The fraction eluted with $10 \%$ AcOEt in hexane $(\mathrm{v} / \mathrm{v})$ afforded 13 $(410 \mathrm{mg}, 89 \%)$ as a colorless oil. $[\alpha]_{\mathrm{D}}^{27}+5.56 \quad\left(c=2.16, \mathrm{CHCl}_{3}\right)$. IR (neat): 1735, 1635, $1105 \mathrm{~cm}^{-1} \cdot{ }^{1} \mathrm{H}-\mathrm{NMR}\left(\mathrm{CDCl}_{3}\right)$ $\delta: 2.04\left(3 \mathrm{H}, \mathrm{s}, \mathrm{COCH}_{3}\right), 3.39\left(3 \mathrm{H}, \mathrm{s}, \mathrm{OCH}_{3}\right), 4.70\left(2 \mathrm{H}, \mathrm{s}, \mathrm{OCH}_{2} \mathrm{O}\right) . \mathrm{MS} m / z: 371\left(\mathrm{M}^{+}+1\right), 370\left(\mathrm{M}^{+}\right), 339,281$.

$(1 R, 2 S, 3 S)$-1-Hydroxymethyl-3-(2-methoxyethoxymethoxymethyl)-2-(7-octenyl)cyclopentane (14)-CCompound 13 was added dropwise with stirring to a suspension of $\mathrm{LiAlH}_{4}(65 \mathrm{mg})$ in ether $(20 \mathrm{ml})$ at $0 \mathrm{C}$, and stirred for $4 \mathrm{~h}$ at room temperature. The work-up afforded a crude oil $(449 \mathrm{mg})$, which was subjected to column chromatography on silica gel $(15 \mathrm{~g})$. The fraction eluted with $30 \%$ AcOEt in hexane $(\mathrm{v} / \mathrm{v})$ afforded $\mathbf{1 4}(347 \mathrm{mg}, 93 \%)$ as a colorless oil $[\alpha]_{\mathrm{D}}^{28}+7.50\left(c=2.10, \mathrm{CHCl}_{3}\right)$. IR (neat): $3425,1640,1110 \mathrm{~cm}^{-1} \cdot{ }^{1} \mathrm{H}-\mathrm{NMR}\left(\mathrm{CDCl}_{3}\right) \delta: 1.64(1 \mathrm{H}, \mathrm{s}, \mathrm{OH}), 3.38(3 \mathrm{H}, \mathrm{s}$, $\left.\mathrm{OCH}_{3}\right), 4.84-5.12\left(2 \mathrm{H}, \mathrm{m},=\mathrm{CH}_{2}\right), 5.82(1 \mathrm{H}, \mathrm{m}, \mathrm{CH}=) . \mathrm{MS} m / z: 329\left(\mathrm{M}^{+}+1\right), 252,239,221$.

$(1 R, 2 R, 3 S)$-1-Mesyloxymethyl-3-(2-methoxyethoxymethoxymethyl)-2-(7-octenyl)cyclopentane (15)-—In a manner similar to that described for the preparation of $\mathbf{1 0}, \mathbf{1 4}(215 \mathrm{mg})$ afforded $\mathbf{1 5}(261 \mathrm{mg}, 98 \%)$ as a colorless oil $[\alpha]_{\mathrm{D}}^{28}+1.26\left(c=2.11, \mathrm{CHCl}_{3}\right)$. IR (neat): 1635, 1355, 1175, $1110 \mathrm{~cm}^{-1} \cdot{ }^{1} \mathrm{H}-\mathrm{NMR}\left(\mathrm{CDCl}_{3}\right) \delta: 3.00\left(3 \mathrm{H}, \mathrm{s}, \mathrm{SO}_{2} \mathrm{CH}_{3}\right)$, $3.39\left(3 \mathrm{H}, \mathrm{s}, \mathrm{OCH}_{3}\right), 4.84-5.10\left(2 \mathrm{H}, \mathrm{m},=\mathrm{CH}_{2}\right), 5.82(1 \mathrm{H}, \mathrm{m}, \mathrm{CH}=)$. MS $m / z: 407\left(\mathrm{M}^{+}+1\right), 376,361,299$.

$(1 R, 2 R, 3 S)$-1-Iodomethyl-3-(2-methoxyethoxymethoxymethyl)-2-(7-octenyl)cyclopentane (16) - - A mixture of $15(721 \mathrm{mg})$ and $\mathrm{NaI}(532 \mathrm{mg})$ in HMPA $(3 \mathrm{ml})$ was heated under reflux for $6 \mathrm{~h}$, diluted with brine $(10 \mathrm{ml})$, and extracted with AcOEt. The AcOEt extract was washed, and dried, then concentrated in vacuo to leave an oily residue, which was purified by column chromatography on silica gel $(15 \mathrm{~g})$. The fraction eluted with $20 \%$ AcOEt in hexane $(\mathrm{v} / \mathrm{v})$ gave $16(692 \mathrm{mg}, 89 \%)$ as a yellow oil. $[\alpha]_{\mathrm{D}}^{25}-12.12^{\circ}\left(c=2.00, \mathrm{CHCl}_{3}\right)$. IR (neat): $1635,1110,905 \mathrm{~cm}^{-1} .{ }^{1} \mathrm{H}^{-}$ NMR $\left(\mathrm{CDCl}_{3}\right) \delta: 3.38\left(3 \mathrm{H}, \mathrm{s}, \mathrm{OCH}_{3}\right), 4.82-5.12\left(2 \mathrm{H}, \mathrm{m},=\mathrm{CH}_{2}\right), 5.80(1 \mathrm{H}, \mathrm{m}, \mathrm{CH}=)$. MS $m / z: 439\left(\mathrm{M}^{+}+1\right), 407$, 362,331 .

(2R,3S)-1-Methylene-3-(2-methoxyethoxymethoxymethyl)-2-(7-octenyl)cyclopentane (17) - A mixture of $16(240 \mathrm{mg})$ and tert-BuOK $(123 \mathrm{mg})$ in DMSO $(5 \mathrm{ml})$ was stirred for $10 \mathrm{~min}$ at room temperature, diluted with $3 \%$ aq. $\mathrm{HCl}(10 \mathrm{ml})$, and extracted with ether. The ether extract was washed, dried, and then concentrated in vacuo to afford an oily residue, which was chromatographed on silica gel $(5 \mathrm{~g})$. The fraction eluted with $20 \%$ ether in hexane $(\mathrm{v} / \mathrm{v})$ afforded $17(160 \mathrm{mg}, 94 \%)$ as a colorless oil. $[\alpha]_{\mathrm{D}}^{25}-1.54 \quad\left(c=2.26, \mathrm{CHCl}_{3}\right)$. IR (neat): 1650, 1640,1110 $1040 \mathrm{~cm}^{-1} .{ }^{1} \mathrm{H}-\mathrm{NMR}\left(\mathrm{CDCl}_{3}\right) \delta: 4.68-5.12\left(4 \mathrm{H}, \mathrm{m},=\mathrm{CH}_{2} \times 2\right), 4.70\left(2 \mathrm{H}, \mathrm{s}, \mathrm{OCH}_{2} \mathrm{O}\right), 5.82(1 \mathrm{H}, \mathrm{m}, \mathrm{CH}=) . \mathrm{MS} m / z:$ $311\left(\mathrm{M}^{+}+1\right), 234,220$. Anal. Calcd for $\mathrm{C}_{19} \mathrm{H}_{34} \mathrm{O}_{3}: \mathrm{C}, 73.50 ; \mathrm{H}, 11.04$. Found: C, 73.38; H, 11.19.

(2R,3S)-2-(6-Formylhexyl)-3-(2-methoxyethoxymethoxymethyl)-1-cyclopentanone (18)_Ozone gas was bubbled into a solution of $17(155 \mathrm{mg})$ in $\mathrm{CH}_{2} \mathrm{Cl}_{2}(15 \mathrm{ml})$ at $-78 \mathrm{C}$, and the reaction was monitored by TLC. The resulting ozonide was decomposed with $\mathrm{Zn}$ powder $(460 \mathrm{mg})$ and $\mathrm{AcOH}(3 \mathrm{ml})$ at 10 to $20 \mathrm{C}$. The $\mathrm{Zn}$ powder was filtered off, and the filtrate was concentrated in vacuo, diluted with brine $(20 \mathrm{ml})$, and then extracted with AcOEt. The AcOEt extract was washed, and dried. The solvent was removed in vacuo to afford an oily residue, which was purified by column chromatography on silica gel $(2 \mathrm{~g})$. The fraction eluted with $30 \%$ AcOEt in hexane (v/v) afforded 18 $(108 \mathrm{mg}, 68 \%)$ as a colorless oil. $[\alpha]_{\mathrm{D}}^{26}-20.87^{\circ}\left(c=2.18, \mathrm{CHCl}_{3}\right)$. IR (neat): $2720,1735,1110 \mathrm{~cm}^{-1} \cdot{ }^{1} \mathrm{H}-\mathrm{NMR}\left(\mathrm{CDCl}_{3}\right)$ $\delta: 3.40\left(3 \mathrm{H}, \mathrm{s}, \mathrm{OCH}_{3}\right), 4.72\left(2 \mathrm{H}, \mathrm{s}, \mathrm{OCH}_{2} \mathrm{O}\right), 9.76(1 \mathrm{H}, \mathrm{t}, J=2 \mathrm{~Hz}, \mathrm{CHO}) . \mathrm{MS} m / z: 315\left(\mathrm{M}^{+}+1\right), 314\left(\mathrm{M}^{+}\right), 299,269$.

(2R,3S)-2-(6-Methoxycarbonylhexyl)-3-(2-methoxyethoxymethoxymethyl)-1-cyclopentanone (19)-—Jones reagent $(0.2 \mathrm{ml})$ was added dropwise to a stirred solution of $18(92 \mathrm{mg})$ in acetone $(10 \mathrm{ml})$ at $-10 \mathrm{C}$. After $0.5 \mathrm{~h}$, the excess reagent was decomposed with isopropanol, and the reaction mixture was diluted with brine $(5 \mathrm{ml})$, then extracted with ether. The ether extract was dried, and esterified with $\mathrm{CH}_{2} \mathrm{~N}_{2}$ in the usual manner. Removal of the solvent in vacuo afforded an oily residue, which was subjected to column chromatography on silica gel ( $2 \mathrm{~g})$. The fraction eluted with $20 \%$ AcOEt in hexane $(\mathrm{v} / \mathrm{v})$ gave $19(86 \mathrm{mg}, 85 \%)$ as a colorless oil. $[\alpha]_{\mathrm{D}}^{24}-18.98 \quad(c=2.06$, $\left.\mathrm{CHCl}_{3}\right)$. IR (neat): $1735,1170,1110,1040 \mathrm{~cm}^{-1} \cdot{ }^{1} \mathrm{H}-\mathrm{NMR}\left(\mathrm{CDCl}_{3}\right) \delta: 3.38\left(3 \mathrm{H}, \mathrm{s}, \mathrm{OCH}_{3}\right), 3.70\left(3 \mathrm{H}, \mathrm{s}, \mathrm{COOCH}_{3}\right)$, 
$4.72\left(2 \mathrm{H}, \mathrm{s}, \mathrm{OCH}_{2} \mathrm{O}\right) . \mathrm{MS} m / z: 345\left(\mathrm{M}^{+}+1\right), 313\left(\mathrm{M}^{+}-\mathrm{OCH}_{3}\right), 299,269$.

(2R,3S)-3-Hydroxymethyl-2-(6-methoxycarbonylhexyl)-1-cyclopentanone (20)- $-\mathrm{TiCl}_{4}(142 \mathrm{mg})$ in $\mathrm{CH}_{2} \mathrm{Cl}_{2}$ ( $1 \mathrm{ml}$ ) was added dropwise to a stirred solution of $19(86 \mathrm{mg})$ in $\mathrm{CH}_{2} \mathrm{Cl}_{2}(2 \mathrm{ml})$ at $0 \mathrm{C}$, and the whole was stirred for $0.5 \mathrm{~h}$. The reaction mixture was diluted with brine $(10 \mathrm{ml})$, and extracted with $\mathrm{CH}_{2} \mathrm{Cl}_{2}$. The $\mathrm{CH}_{2} \mathrm{Cl}_{2}$ extract was washed, and dried, then concentrated in vacuo to afford an oily residue, which was purified by column chromatography on silica gel (3g). The fraction eluted with $25 \%$ AcOEt in hexane (v/v) afforded ( -$)-20(39 \mathrm{mg}, 61 \%)$ as a colorless oil. Compound (-)-20 was identical with the ( \pm )-standard sample ${ }^{11}$ in terms of the ${ }^{1} \mathrm{H}-\mathrm{NMR}$ and the IR spectra. $[x]_{\mathrm{D}}^{2,3}-39.57\left(c=1.87, \mathrm{CHCl}_{3}\right)$. IR (neat): $3470,1740,1170,1045 \mathrm{~cm}^{-1} \cdot{ }^{1} \mathrm{H}-\mathrm{NMR}\left(\mathrm{CDCl}_{3}\right) \delta: 1.10-2.64$ $\left(18 \mathrm{H}, \mathrm{m}, \mathrm{CH}_{2} \times 8, \mathrm{CH} \times 2\right), 1.76(1 \mathrm{H}, \mathrm{s}, \mathrm{OH}), 3.36-3.92\left(2 \mathrm{H}, \mathrm{m}, \mathrm{CH}_{2} \mathrm{O}\right), 3.65\left(3 \mathrm{H}, \mathrm{s}, \mathrm{COOCH}_{3}\right) . \mathrm{MS} m / z: 257$ $\left(\mathrm{M}^{+}+1\right), 256\left(\mathrm{M}^{+}\right), 238,225$. Anal. Calcd for $\mathrm{C}_{14} \mathrm{H}_{24} \mathrm{O}_{4}: \mathrm{C}, 65.59 ; \mathrm{H}, 9.44$. Found: C, 65.65; H, 9.59.

\section{References and Notes}

1) a) G. Sabbioni, M. L. Shea, and J. B. Jones, J. Chem. Soc., Chem. Commun., 1984, 236; b) P. Mohr, N. W. Sarcevic, C. Tamm, K. Gawronska, and J. K. Gawronski, Helv. Chim. Acta, 66, 2501 (1983); c) K. Laumen and M. Schneider, Tetrahedron Lett., 26, 2073 (1985).

2) J. B. Jones, R. S. Hinks, and P. G. Hultin, Can. J. Chem., 63, 452 (1985).

3) W. Kasel, P. G. Hultin, and J. B. Jones, J. Chem. Soc., Chem. Commun., 1985, 1563.

4) For the enzymatic hydrolysis of 1,3-diacetoxy-4-cyclopentene, see: K. Laumen and M. Schneider, Tetrahedron Lett., 25, 5875 (1985).

5) A. Greane and P. Crabbe, Tetrahedron Lett., 1975, 2215.

6) E. J. Corey and R. L. Danheiser, Tetrahedron Lett., 1973, 447.

7) Preliminary hydrolysis of $\mathbf{2 a}$ with PLE resulted in only $15 \%$ ee.

8) Optical purities of $\mathbf{5 a}, \mathbf{b}$ were determined by $400 \mathrm{MHz}{ }^{1} \mathrm{H}-\mathrm{NMR}\left(\mathrm{CDCl}_{3}\right)$ spectroscopy after conversion to the corresponding (+)-MTPA esters. In the spectrum of the $(+)$-MTPA ester of $( \pm)-5 \mathbf{a}$, methylene protons ( $\left.-\mathrm{CH}_{2} \mathrm{O}-\mathrm{MTPA}\right)$ were observed as two pairs of double-doublet signals originating from two diastereomers at $\delta 4.107(\mathrm{dd}, J=10.8,7.9 \mathrm{~Hz}), 4.182(\mathrm{dd}, J=10.8,7.7 \mathrm{~Hz}), 4.278(\mathrm{dd}, J=10.8,5.1 \mathrm{~Hz}), 4.340(\mathrm{dd}, J=10.8,5.1 \mathrm{~Hz})$. The methylene protons in the (+)-MTPA ester of (-)-5a (Table I, run 3) were observed as a major pair of double-double signals at $\delta 4.182$ and 4.278 , and the other pair of double-doublet signals at $\delta 4.107$ and 4.340 was remarkably reduced. On the basis of the relative intensity of these two pairs, the optical purity of (-)-5a was calculated. By using a similar technique, the optical purity of $(-)-5 \mathbf{b}$ was determined. (+)-MTPA ester of $( \pm)$ 5b: $\delta 4.104(\mathrm{dd}, J=10.9,7.9 \mathrm{~Hz}), 4.179(\mathrm{dd}, J=10.8,7.6 \mathrm{~Hz}), 4.274(\mathrm{dd}, J=10.8,5.1 \mathrm{~Hz}), 4.336(\mathrm{dd}, J=10.9$, $5.1 \mathrm{~Hz}) .(+)$-MTPA ester of (-)-5b: $\delta 4.179$ and 4.274 .

9) H. Suemune, T. Kawahara, and K. Sakai, Chem. Pharm. Bull., 34, 550 (1986).

10) A route to $( \pm)$-11-deoxy PGs from the corresponding ( \pm )-aldehyde was established by Greane and Crabbe. ${ }^{5)}$

11) The $( \pm)$-standard sample was synthesized by an alternative method. ${ }^{13}$ )

12) The assignment of $\mathrm{C}_{1}$ - and $\mathrm{C}_{3}-\mathrm{H}$ in $\mathbf{3 a}$, b was based on: H. B. Kagan, "Stereochemistry," Vol. 1, George Thieme Publishers, Stuttgart, 1977, p. 92.

13) K. Sakai, J. Ide, O. Oda, and N. Nakamura, Tetrahedron Lett., 1972, 1287. 